\title{
Identification of genetic polymorphisms in DNA repair xenoderma pigmentosum group $D$ gene and its association with head and neck cancer susceptibility in rural Indian population: a hospital based case-control study from south-western Maharashtra, India
}

\author{
Kailas D. Datkhile ${ }^{1}$, Rohit D. Vhaval ${ }^{1}$, Madhavi N. Patil ${ }^{1}$, Tejasvi S. Khamkar ${ }^{1}$, Pratik P. \\ Durgawale $^{1}$, Pandurang G. Chougule ${ }^{2}$, Neville Tata ${ }^{2}$, Ritwij Patankar ${ }^{2}$, \\ Anand Gudur ${ }^{3}$, Satish V. Kakade ${ }^{4}$
}

\begin{abstract}
${ }^{1}$ Molecular and Genetic Laboratory, Krishna Institute of Medical Sciences, Karad, Satara, 415539, Maharashtra, India ${ }^{2}$ Department of Surgery, Krishna Institute of Medical Sciences, Karad, Satara, 415539, Maharashtra, India ${ }^{3}$ Department of Oncology, Krishna Institute of Medical Sciences, Karad, Satara, 415539, Maharashtra, India ${ }^{4}$ Department of Preventive and Social Medicine, Krishna Institute of Medical Sciences, Karad, Satara, 415539, Maharashtra, India
\end{abstract}

Received: 17 March 2016

Revised: 18 March 2016

Accepted: 22 April 2016

\author{
*Correspondence: \\ Dr. Kailas D. Datkhile, \\ E-mail: kddatkhile@gmail.com
}

Copyright: () the author(s), publisher and licensee Medip Academy. This is an open-access article distributed under the terms of the Creative Commons Attribution Non-Commercial License, which permits unrestricted non-commercial use, distribution, and reproduction in any medium, provided the original work is properly cited.

\begin{abstract}
Background: Smoking and alcohol related head and neck cancer is a major concern of health risk in developing countries, such as India. In this study, we aimed to determine the frequency of polymorphisms in DNA repair gene, xeroderma pigmentosum complementation group D $(X P D)$ at codon (cd) 156, cd199, cd320, cd751 in patients of oral cancer from South-Western Maharashtra, India and to evaluate their association with oral cancer development.

Methods: We used polymerase chain reaction-restriction fragment length polymorphism (PCR-RFLP) to analyze $X P D$ gene polymorphisms in 320 patients with oral cancer and in 400 age and sex matched disease-free controls.

Results: There was no significant difference in the genotype distribution between oral cancer patients and controls for each polymorphism ( $p>0.05$ ) except XPD199. The result from our study showed that allele frequencies of selected genes were not statistically different between the groups for XPD Arg156, XPD Asn320, XPD Gln751. XPDMet199 $(\mathrm{OR}=29.44 ; 95 \% \mathrm{CI}=(18.47-46.92) ; p \leq 0.0001)$ genotypes significantly increased the risk of head and neck cancer.

Conclusions: This study indicates that polymorphisms in cd199 of XPD gene could play a role in modifying genetic susceptibility of individual to head and neck cancer in Maharashtra patients. Thus, the case-control study suggest that selected DNA repair genes represent genetic determinants in oral carcinogenesis along with other risk factors in the rural Indian population.
\end{abstract}

Keywords: Genetic polymorphisms, XPD, Cancer risk, Genotyping, PCR-RFLP

\section{INTRODUCTION}

Oral cancer is the fifth most common type of cancer worldwide and second in the developing world. ${ }^{1,2}$ In the Indian subcontinent head and neck cancer (HNC) is the frequent malignancy, accounting up to $40-50 \%$ of all malignant cancers. ${ }^{3}$ The incidence of HNC has significantly increased in the past 20 years and has become the fourth most common cause of cancer among men and third most common cancer among women in 
India. Among the major documented risk factors associated with HNC are tobacco smoking's, alcohol consumption followed by diet, oral health or exposure to environmental carcinogens., ${ }^{2,-6}$ Carcinogenic molecules from these carcinogens are known to cause oxidative DNA damage to epithelial cells, but such damage is known to be corrected by some DNA repair mechanisms. $^{7,8}$ It is also believed that along with the environmental factors, the host factors including individual's genetic susceptibility related to genetic polymorphisms of various genes including those involved in DNA repair pathway is also likely to play a role in the development of oral cancer. ${ }^{9}$ Though the genetic factors are considered of great importance to cancer risk through the modulation of DNA repair but the genomic etiology of HNC is largely unknown.

There are three major pathways involved in DNA damage and repair which play a pivotal role in maintenance of genomic integrity such as base excision repair (BER), nucleotide excision repair (NER) and double strand break repair (DSBR). ${ }^{10}$ But it is not yet clear which DNA repair pathways or enzymes are most important for protection against HNC. The NER pathway is an important mechanism that repairs DNA damage which involved in the removal of variety of bulky DNA lesions such as ultra violet light induced pyrimidine dimmer, other photoproducts, larger chemical adducts and crosslinks.

Human xenoderma pigmentosum complementation group $\mathrm{D}$ (XPD) is one of the major gene involved in NER pathway through recognition and repair of thymidine dimers. XPD have DNA helicase activity which participates in NER pathway and basal transcription through stabilizing the transcription factor complex TFIIH $^{11}$. Hundreds of polymorphisms in DNA repair genes associated with cancer risk have been identified ${ }^{12-13}$ but their effects on repair function have not been well characterized.

Some of them are X-ray crosscomplementing group (XRCC), Xenoderma pigmentosun complementation group D (XPD), xenoderma pigmentosum complementation group C (XPC) and xenoderma pigmentosum complementation group $\mathrm{G}$ (XPG) which have been frequently studied and there is a growing body of evidence that polymorphisms of these genes may have some phenotypic significance. Previous studies on XPD suggested that XPD polymorphisms were associated with risk of skin cancer, breast cancer, gliomas, and bladder cancer in Caucasian, Americans, British and Chinese populations. ${ }^{14-19}$

Few molecular epidemiologic studies have evaluated the association of HNC with functional genetic variants in the XPD genes, but in some of the studies the results are contradictory rather than convincing. ${ }^{20-25}$ Also, the earlier observations were not consistent in terms of their roles in oral cancer susceptibility and therefore the influence of the polymorphisms of XPD genes on DNA repair capacity is still unclear. It is also uncertain which DNA repair pathway genes may be more important for protection against head and neck cancer. In earlier studies we have shown that polymorphisms in BER pathway genes especially XRCC1, XRCC4, XRCC5 and XRCC7 plays an important role in susceptibility of head and neck cancer in rural population of south-western Maharashtra, India. $^{26}$

In continuation with this, we also hypothesized that the inherited polymorphisms of NER pathway genes may contribute to genetic susceptibility to head and neck cancer. To test this hypothesis we also focused on different genetic polymorphisms of NER pathway genes especially XPD to evaluate their role in head and neck cancer if any.

We performed a hospital based case-control study using a polymerase chain reaction based restriction fragment length polymorphism (PCR-RFLP) assay to genotype the polymorphisms of selected DNA repair genes in relation to head and neck cancer susceptibility in a rural population of south-western Maharashtra from India. We determined the genotypic frequency of polymorphisms of the (A) XPD C22541A at codon 156 of the exon 6 (B) XPD C23047G at codon199 of the exon 8 (C) XPD G23592A at codon 312 in the exon 10 and (D) XPD A $35931 \mathrm{C}$ at codon 751 in the exon 23 using the restriction enzymes TfiI, DpnII, StyI and PstI respectively. Multivariate logistic regression analysis was performed to calculate adjusted odds ratio (OR) and $95 \%$ confidence intervals (CIs).

\section{METHODS}

This study was a hospital based, case-control study conducted in rural areas of south-western Maharashtra from India. Study participants included 320 patients, newly diagnosed with head and neck cancer and 400 healthy, cancer free, age and sex matched individuals were selected as controls living in the same residential areas as the cases. All cases ranged in age from $30-80$ years (Mean \pm SD) 54.42 \pm 12.95 were recruited immediately after being diagnosed. Trained interviewers used a structured questionnaire to collect personal interview data from the participants regarding demographic factors and known risk factors including occupational history, dietary habits, smoking and drinking status and individual family history of diseases, including cancer.

\section{Genomic DNA isolation from whole blood}

Five milliliter (mL) of whole blood from patients and normal age matched controls was collected in sterile purple top vacutainer after receiving informed consent. Genomic DNA extraction was carried out from the peripheral blood sample using Purelink genomic DNA extraction and purification Kit (Invitrogen, Life technologies) following the manufacturer's instructions. 


\section{Genotyping assays}

Genotyping of XPD gene were performed by PCR-RFLP methods with appropriate primer sets (Table 1). The primers were designed to amplify the regions of DNA that contain polymorphic sites of interest: (A) XPD C22541A codon 156 in the exon 6 (B) XPD C23047G at codon 199 of the exon 8 (C) XPD G23592A at codon 312 in the exon 10 and (D) XPD A35931C at codon 751 in the exon 23 .

Table 1. Details of PCR and RFLP procedures and expected products of XPD genes.

\begin{tabular}{|c|c|c|c|c|c|}
\hline Gene & $\begin{array}{l}\text { Primers } \\
\text { Forward/Reverse }\end{array}$ & PCR conditions & $\begin{array}{l}\text { PCR } \\
\text { Product }\end{array}$ & $\begin{array}{l}\text { Restriction } \\
\text { enzyme }\end{array}$ & Restriction products \\
\hline $\begin{array}{l}X P D \\
\text { C22541A } \\
\text { Arg156Arg } \\
\text { codon 156 } \\
\text { Ex-6 }\end{array}$ & $\begin{array}{l}5 \text { ' - tgg agt gct atg gca } \\
\text { cga tct ct }-3^{\prime} \\
5^{\prime}-\text { cca tgg gca tca aat } \\
\text { tcc tgg ga }-3 \text { ' }\end{array}$ & $\begin{array}{l}95^{\circ} \mathrm{C}-5 \mathrm{~min}, 30 \\
\text { cycles of } 95^{\circ} \mathrm{C}-30 \\
\text { sec, } 60^{0} \mathrm{C}-30 \mathrm{sec}, \\
72^{\circ} \mathrm{C}-30 \mathrm{sec}, 72^{\circ} \mathrm{C}- \\
5 \mathrm{~min}\end{array}$ & $644 \mathrm{bp}$ & $1 \mathrm{U}$ of $\mathrm{TfiI}$ & $\begin{array}{l}\text { C/C: } 587 \mathrm{bp}, 57 \mathrm{bp} \\
\text { C/A: } 587 \mathrm{bp}, 474 \mathrm{bp}, \\
113 \mathrm{bp}, 57 \mathrm{bp} \\
\text { A/A: } 474 \mathrm{bp}, 113 \mathrm{bp}, 57 \mathrm{bp}\end{array}$ \\
\hline $\begin{array}{l}X P D \\
\text { C23047G } \\
\text { Ile199Met } \\
\text { codon199 } \\
\text { Ex-8 }\end{array}$ & $\begin{array}{l}5^{\prime}-\text { ctg ttg gtg ggt gcc } \\
\text { cgt atc tgt tgg tct }-3^{\prime} \\
5^{\prime}-\text { taa tat cgg ggc tca } \\
\text { ccc tgc agc act tcc }- \\
3^{\prime}\end{array}$ & 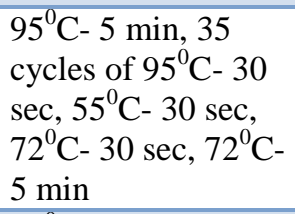 & $357 \mathrm{bp}$ & 1U DpnII & $\begin{array}{l}\text { Control cut: } 357 \mathrm{bp} \\
\text { Ile/Ile:176bp, 73bp } \\
\text { Ile/Met:243bp,176bp,73bp } \\
\text { Met/Met: } 243 \mathrm{bp}\end{array}$ \\
\hline $\begin{array}{l}\text { XPD } \\
\text { G23591A } \\
\text { Asp312Asn } \\
\text { codon312 } \\
\text { Ex-10 }\end{array}$ & $\begin{array}{l}5^{\prime} \text {-ctg ttg gtg ggt gcc } \\
\text { cgt atc tgt tgg tct- } 3^{\prime} \\
5^{\prime} \text {-taa tat cgg ggc tca } \\
\text { ccc tgc agc act tcc t- } \\
3^{\prime}\end{array}$ & $\begin{array}{l}95^{0} \mathrm{C}-5 \mathrm{~min}, 35 \\
\text { cycles of } 95^{0} \mathrm{C}-30 \\
\text { sec, } 62^{0} \mathrm{C}-45 \mathrm{sec}, \\
72^{0} \mathrm{C}-30 \mathrm{sec}, 72^{0} \mathrm{C}- \\
5 \mathrm{~min}\end{array}$ & $751 \mathrm{bp}$ & $1 \mathrm{U}$ of StyI & $\begin{array}{l}\text { Asp/Asp:507bp, 244bp } \\
\text { Asp/Asn:507bp, 474bp, } \\
\text { 244bp, 33bp } \\
\text { Asn/Asn:474bp,244bp } \\
\text { 33bp }\end{array}$ \\
\hline $\begin{array}{l}X P D \\
\text { A35931C } \\
\text { Lys } 751 G l n \\
\text { codon } 751 \\
\text { Ex-23 }\end{array}$ & $\begin{array}{l}5^{\prime}-\text { caa gta cag cca ggt } \\
\text { cct ag -3' } \\
5^{\prime}-\text { cct tcc ctc atc tgg } \\
\text { agt ac }-3 \text { ' }\end{array}$ & $\begin{array}{l}95^{0} \mathrm{C}-5 \mathrm{~min}, 30 \\
\text { cycles of } 95^{\circ} \mathrm{C}-30 \\
\mathrm{sec}, 55^{\circ} \mathrm{C}-30 \mathrm{sec}, \\
72^{0} \mathrm{C}-30 \mathrm{sec}, 72^{0} \mathrm{C}- \\
5 \mathrm{~min}\end{array}$ & $436 \mathrm{bp}$ & 2U PstI & $\begin{array}{l}\text { Lys/Lys (A/A): } \\
\text { 290bp, 146 bp } \\
\text { Lys/Gln (A/C): } \\
\text { 290bp, 227bp, 146bp, } \\
\text { 63bp } \\
\text { Gln/Gln (C/C) } 227 \mathrm{bp}, \\
\text { 146bp, 63bp }\end{array}$ \\
\hline
\end{tabular}

The PCR amplification were carried out separately under different conditions in 20 micro liter $(\mu \mathrm{L})$ reaction mixtures containing $1 \mathrm{X}$ PCR buffer $(10$ mili molar $(\mathrm{mM})$ Tris- $\mathrm{HCl}$ ( $\mathrm{pH} 9.0$ ), $50 \mathrm{mM} \mathrm{KCl} 1.5 \mathrm{mM} \mathrm{MgCl} 2,0.01 \%$ gelatin), $0.2 \mathrm{mM}$ each dNTP, 10 picomole (pmol) of each primer listed in Table-1, 1U Taq DNA polymerase (GeNei, Merck Bioscience) and 100 nanogram (ng) of purified genomic DNA template. The reaction mixtures were subjected to PCR amplification with a Master Cycler Gradient PCR (Eppendorf). After performing PCR programme for each of the reactions, the PCR products were analyzed by agarose gel electrophoresis in TrisAcetate-EDTA (TAE) buffer.

The agarose gels were stained with ethidium bromide (10 $\mathrm{mg} / \mathrm{mL}$ ) and visualized under UV Transilluminator and photographed in gel documentation system (BioRad Laboratories). After confirmation of DNA amplification, each PCR product was digested with an appropriate restriction enzyme as shown in Table-1 for genotyping. Ten $\mu \mathrm{L}$ of the PCR products were digested at $37^{\circ} \mathrm{C}$ overnight with specific restriction enzymes in $20 \mu \mathrm{L}$ reaction mixtures containing buffer supplied with each restriction enzyme. After the overnight incubation, digestion products were then separated on a $2-3 \%$ low EEO agarose (GeNei) gel at 100 Volts for 30 min stained with ethidium bromide and photographed with gel documentation system.

\section{Statistical analysis}

All statistical analyses were performed using SPSS 11.5 for windows software. The associations between the XPD genotypes and risk of HNC with or without smoking and drinking history were studied using odds ratio (OR). Both the univariate and multivariate logistic regression analyses were employed to calculate the adjusted odds ratios (ORs) and 95\% confidence intervals (CIs) to determine the cancer risk associated with genotypes.

\section{RESULTS}

During the study period, 320 patients with oral cancer met the eligibility criteria for this study and 400 controls were selected to match these cases. The characteristics of age and sex matched cases and controls are presented in 
Table 2. The $($ Mean \pm SD) age in years was $54.42 \pm 12.95$ for the cases and 52.84 $\pm 12.94(P<0.05)$ for the controls, however there was no significant difference in mean age between cases and controls. Also, there was no significant difference in males of cases $(62.50 \%)$ and of controls $(65.00 \%)$. There were more smokers $(78.13 \%)$ and drinkers $(68.75 \%)$ in cases as compared to controls $20.0 \%$ and 12.50 .00$)$ respectively enrolled in this study.

Table 2: Distribution comparisons of selected demographic characteristics of head and neck cancer cases and healthy controls from rural areas of Maharashtra in India.

\begin{tabular}{|c|c|c|c|c|c|}
\hline \multirow{3}{*}{$\begin{array}{l}\text { Variable } \\
\text { Age }(\text { Mean } \pm \text { SD) years }\end{array}$} & \multicolumn{2}{|c|}{ Cases $\mathbf{N}=\mathbf{3 2 0}$} & \multicolumn{2}{|c|}{ Controls $N=400$} & \multirow[t]{2}{*}{$P$-Value based on $\chi^{2}$} \\
\hline & \multicolumn{2}{|c|}{$54.42 \pm 12.95$} & \multicolumn{2}{|c|}{$52.84 \pm 12.94$} & \\
\hline & No. & $(\%)$ & No. & $(\%)$ & \\
\hline$\leq 50$ & 122 & 38.13 & 184 & 46.00 & $<0.05$ \\
\hline $51-60$ & 86 & 26.87 & 100 & 25.00 & \\
\hline $61-70$ & 84 & 26.25 & 86 & 21.50 & \\
\hline$>70$ & 28 & 8.75 & 30 & 7.50 & \\
\hline Sex & & & & & 0.44 \\
\hline Male & 200 & 62.50 & 260 & 65.00 & \\
\hline Female & 120 & 37.50 & 140 & 35.00 & \\
\hline Tobacco smoking Status & & & & & $<0.001$ \\
\hline Smokers Current & 253 & 78.13 & 80 & 20.00 & \\
\hline Non smokers & 67 & 21.87 & 320 & 80.00 & \\
\hline Alcohol status & & & & & $<0.001$ \\
\hline Drinkers & 220 & 68.75 & 50 & 12.50 & \\
\hline Non-drinkers & 100 & 31.25 & 350 & 87.50 & \\
\hline Diet & & & & & 0.04 \\
\hline Vegeterian & 90 & 28.13 & 140 & 35.00 & \\
\hline Non-vegeterian & 10 & 3.12 & 20 & 5.00 & \\
\hline Mixed & 220 & 68.75 & 240 & 60.00 & \\
\hline Education & & & & & 0.73 \\
\hline High School & 205 & 64.06 & 180 & 45.00 & \\
\hline High School graduate (12 y) & 70 & 21.88 & 120 & 30.00 & \\
\hline College /Graduate & 45 & 14.06 & 100 & 25.00 & \\
\hline Economic status & & & & & 0.56 \\
\hline Middle & 112 & 35.00 & 148 & 37.10 & \\
\hline Poor & 208 & 65.00 & 251 & 62.90 & \\
\hline \multicolumn{6}{|l|}{ Family history of Cancer } \\
\hline Yes & 20 & 6.25 & 0 & 0.00 & 0.2 \\
\hline No & 300 & 93.75 & 400 & 100 & \\
\hline
\end{tabular}

\section{Association of polymorphisms in XPD gene and smoking and drinking status in cases of $\mathrm{HNC}$ and age and sex matched controls}

XPD gene comprises 23 exons and spans $\sim 19.20 \mathrm{~kb}$ on chromosome 19q13.3. XPD gene coding regions have been identified in six major SNP sites corresponding to nucleotide changes were C22541A, C23047G, C23051T, G23591A, C35326T, A35931C corresponding to codons $156,199,201,312,711,751$ respectively. We investigated the distribution and association between the previously described polymorphisms of cd156, cd199, cd312 and cd751 of XPD genes in relation with tobacco, alcohol consumption from rural Maharashtrian population.

\section{(A) XPD C22541A codon 156 exon 6}

The amplification of XPD codon 156 resulted in the product of $644 \mathrm{bp}$. The TfiI enzyme was used to detect the XPDC22541A at codon 156 of exon 6. The PCR amplified products upon treatment with TfiI yielded wildtype (22541C) alleles of 587, 57bp fragments, and the polymorphic (A) allele produces 3 fragments of 474, 113 and $57 \mathrm{bp}$ (Figure 1A). The frequency of XPD 22541CC homozygotes was $53.75 \%$ in cases and $59.50 \%$ in controls whereas the frequency of $22541 \mathrm{~A}$ allele was lower but not significantly in the cases $(13.75 \%)$ than in the controls $(10.0 \%)$. The frequency of XPD22541 CA heterozygotes was $32.50 \%$ in cases and $30.50 \%$ in controls (Table 3). Thus, the $\mathrm{C} \rightarrow \mathrm{A}$ polymorphism in 
exon 6 at nucleotide does not result in an amino acid change at codon 156 in cases as compared to controls.
The average frequency of allele does not show much variation which is in aggrement with previous reports. ${ }^{18,20}$

Table 3: The genotype frequencies of XPD gene variants in untreated head and neck cancer patients and controls.

\begin{tabular}{|c|c|c|c|c|c|c|c|}
\hline Gene & Genotype & $\begin{array}{l}\text { Cases } \\
(n=320)(\%)\end{array}$ & $\begin{array}{l}\text { Control } \\
(n=400)(\%)\end{array}$ & $\begin{array}{l}\text { Odds' Ratio (OR) } \\
\text { (95\% CI) }\end{array}$ & $P$ value & $\begin{array}{l}\text { Adjusted Odds } \\
\text { Ratio } \quad(95 \% \text { CI })\end{array}$ & $\begin{array}{l}P \\
\text { value }\end{array}$ \\
\hline \multirow{4}{*}{$\begin{array}{l}X P D \\
\text { Arg156Arg } \\
\text { codon } 156 \\
\text { Ex-6 } \\
\text { C22541A }\end{array}$} & $\mathrm{CC} / \mathrm{CC}$ & $172(53.75)$ & $238(59.50)$ & 1 & & 1 & \\
\hline & $\mathrm{CC} / \mathrm{AA}$ & $104(32.50)$ & $122(30.50)$ & $1.18(0.85-1.63)$ & 0.32 & $7.15(3.72-13.740$ & $<0.001$ \\
\hline & AA/AA & $44(13.75)$ & $40(10.00)$ & $1.52(0.95-2.43)$ & 0.08 & $9.12(4.14-(20.07)$ & $<0.001$ \\
\hline & $\begin{array}{l}\text { CC/AA+ } \\
\text { AA/AA }\end{array}$ & $148(46.25)$ & $162(40.50)$ & $1.26(0.93-1.70)$ & 0.12 & $8.61(4.74(15.65)$ & $<0.001$ \\
\hline \multirow{4}{*}{$\begin{array}{l}X P D \\
\text { Ile199Met } \\
\text { codon199 } \\
\text { Ex-8 } \\
\text { C23047G }\end{array}$} & $\mathrm{CC} / \mathrm{CC}$ & $40(12.50)$ & $254(63.50)$ & 1 & & 1 & \\
\hline & $\mathrm{CC} / \mathrm{GG}$ & $76(23.75)$ & $102(25.50)$ & $4.73(3.02-7.39)$ & $<0.0001^{*}$ & $0.049(0.024-0.097)$ & $<0.001$ \\
\hline & GG/GG & $204(63.75)$ & $44(11.00)$ & $29.44(18.46-46.93)$ & $<0.0001 *$ & $0.007(0.003-0.014)$ & $<0.001$ \\
\hline & $\begin{array}{l}\text { CC/GG+ } \\
\text { GG/GG }\end{array}$ & $280(87.50)$ & $146(36.50)$ & $12.17(8.25-17.96)$ & $<0.0001^{*}$ & $0.018(0.009-0.033)$ & $<0.001$ \\
\hline \multirow{4}{*}{$\begin{array}{l}X P D \\
\text { Asp312Asn } \\
\text { codon312 } \\
\text { Ex-10 } \\
\text { G23591A }\end{array}$} & GG/GG & $166(51.88)$ & $224(56.00)$ & 1 & & 1 & \\
\hline & GG/AA & $86(26.87)$ & $96(24.00)$ & $1.31(0.92-1.87)$ & 0.29 & $0.96(0.59-1.55)$ & 0.87 \\
\hline & $\mathrm{AA} / \mathrm{AA}$ & $68(21.25)$ & $80(20.00)$ & $1.14(0.78-1.67)$ & 0.48 & $0.79(0.47-1.31)$ & 0.36 \\
\hline & $\begin{array}{l}\text { GG/AA+ } \\
\text { AA/AA }\end{array}$ & $154(48.12)$ & $176(44.00)$ & $1.18(0.87-1.55)$ & 0.26 & $0.87(0.604-1.26)$ & 0.001 \\
\hline \multirow{4}{*}{$\begin{array}{l}X P D \\
\text { Lys } 751 G \ln \\
\text { codon751 } \\
\text { Ex-23 } \\
\text { A35931C }\end{array}$} & AA/AA & $168(52.50)$ & $260(65.00)$ & 1 & & 1 & \\
\hline & $\mathrm{AA} / \mathrm{CC}$ & $100(31.25)$ & $80(20.00)$ & $1.93(1.36-2.75)$ & $<0.001$ & $0.39(0.24-0.63)$ & $<0.001$ \\
\hline & $\mathrm{CC} / \mathrm{CC}$ & $52(16.25)$ & $60(15.00)$ & $1.34(0.88-2.03)$ & 0.16 & $0.89(0.50-1.52)$ & 0.70 \\
\hline & $\begin{array}{l}\mathrm{AA} / \mathrm{CC}+ \\
\mathrm{CC} / \mathrm{CC}\end{array}$ & $152(47.50)$ & $140(35.00)$ & $1.68(1.24-2.26)$ & $<0.001$ & $0.55(0.38-0.81)$ & 0.002 \\
\hline
\end{tabular}

*: Indicates significant Odds Ratio $(\mathrm{p}<0.05), p$ value determined based on $\chi 2$
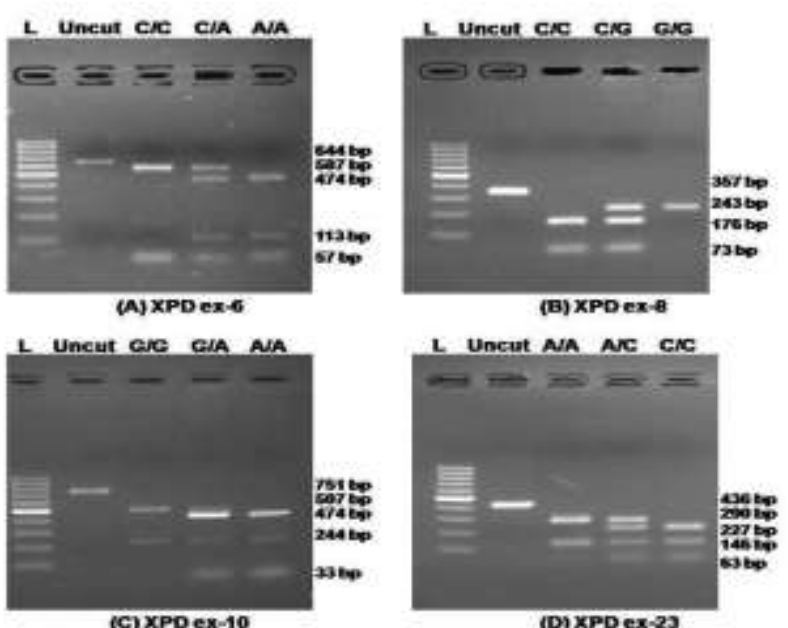

(A) XPD C22541A Codon 156 Ex-6 by TfiI, (Lane 1: 100bp DNA ladder, lane 2: Uncut PCR product, lane 3: CC genotype lane 4: CA genotype, lane 5: AA genotype (B) XPD Ile199Met codon199 Ex-8 by DpnII, (Lane 1: 100 bp DNA ladder, lane 2: Control cut, lane 3: CC genotype, lane 4: CG genotype, lane 5: GG genotype (C) XPD G23592A Asp312Asn cd312 Ex-10 by StyI (Lane 1: 100 bp DNA ladder, lane 2: Uncut PCR product, lane 3: GG genotype, lane 4: GA genotype, lane 5: AA genotype and (D) XPD A35931C Lys751Gln Cd751 Ex-23 by PstI (Lane 1: 100 bp DNA ladder, lane 2: Uncut PCR product, lane 3: AA genotype, lane 4: AC genotype, lane 5: CC genotype.

Figure 1: Representative agarose gel image showing nucleotide polymorphism by PCR-RFLP.

\section{(B) XPD C23047G codon199 exon 8}

The $\mathrm{C} \rightarrow \mathrm{G}$ distribution in codon 199 of the exon 8 results in Ile $\rightarrow$ Met substitution. The frequency of XPD 23047 $C C$ wild type homozygotes was $12.50 \%$ in cases and $63.50 \%$ in controls whereas XPD23047GG variant homozygotes were $63.75 \%$ in cases and $11.0 \%$ in controls.

The frequency of XPD23047CG heterozygotes was $23.75 \%$ in cases and $25.50 \%$ in controls (Table 3 ). The frequency of the XPD $23047 \mathrm{G}$ allele was significantly higher in cases $(0.63)$ than in controls $(0.11)$.

Compared to $23047 \mathrm{CC}$ genotype, the variant genotype 23047GG genotype was associated with oral cancer risk $(0 \mathrm{R}=29.44 ; 95 \% \mathrm{CI}=(18.46-46.93)$ of HNC. Compared with combined group of $23047 \mathrm{CC}+23047 \mathrm{CG}$ genotypes the $23047 \mathrm{GG}$ genotype remained associated with increased risk of $\mathrm{HNC}$.

The XPD 23047GG variant genotype was more frequent in cases $(63.75 \%)$ than in controls whereas the XPD23047CC genotypes were significantly lower in cases $(12.50 \%)$ than in controls $(63.50 \%)$. The 23047 variants of the DNA repair gene XPD are extremely high and contribute significantly to the risk of $\mathrm{HNC}$ in the rural population of south western Maharashtra. 


\section{(C) XPD G23592A codon 312 exon 10}

Table-3 displays the distribution of genotypes and frequency of alleles of the G23592A polymorphisms in patients with head and neck cancer and controls. All distributions of genotypes and alleles were in HardyWeinberg equilibrium. We did not find any significant difference in genotype or allele frequencies in patients with cancer and controls. The $\mathrm{G} \rightarrow \mathrm{A}$ polymorphism in codon 312 of the exon 10 results in Asp $\rightarrow$ Asn substitution in an evolutionary conserved region. The frequency of XPD 23592GG homozygotes was $51.88 \%$ in cases and $56.00 \%$ in controls whereas $23592 A A$ homozygote was $21.25 \%$ in cases and $20.0 \%$ in controls. The frequency of $23592 \mathrm{GA}$ heterozygotes was $26.87 \%$ in cases and $24.00 \%$ in controls (Table-3). This allele frequency in the controls was similar to previously reported studies.

Table 4: Stratification analysis of the demographic factors including age, tobacco smoking and alcohol drinking and distribution of genotypes with odds ratio of the XPD genes in the patients with head and neck cancer and the control group from rural population of south-western Maharashtra, India.

\begin{tabular}{|c|c|c|c|c|c|c|c|c|c|}
\hline \multirow{3}{*}{ Gene } & \multirow{3}{*}{ Genotype } & \multicolumn{8}{|c|}{ Demographic factors } \\
\hline & & \multicolumn{2}{|c|}{ Age (Cases/Control) } & \multicolumn{2}{|c|}{ Sex (Cases/Control) } & \multicolumn{2}{|c|}{$\begin{array}{l}\text { Smoking status } \\
\text { (Cases/Control) }\end{array}$} & \multicolumn{2}{|c|}{$\begin{array}{l}\text { Drinking status } \\
\text { (Cases/Control) }\end{array}$} \\
\hline & & $\begin{array}{l}\leq 50 \\
N=122 / 15 \\
0\end{array}$ & $\begin{array}{l}>50 \\
N=198 / 250\end{array}$ & $\begin{array}{l}\text { Male } \\
\mathrm{N}=200 / \\
260\end{array}$ & $\begin{array}{l}\text { Female } \\
\mathrm{N}=120 / 14 \\
0\end{array}$ & $\begin{array}{l}\text { Smokers } \\
\mathrm{N}=253 / 80\end{array}$ & $\begin{array}{l}\text { Non- } \\
\text { smokers } \\
\mathrm{N}=67 / 320\end{array}$ & $\begin{array}{l}\text { Drinkers } \\
\mathrm{N}=220 / 50\end{array}$ & $\begin{array}{l}\text { Non- } \\
\text { drinkers } \\
\mathrm{N}=100 / 350\end{array}$ \\
\hline \multirow{4}{*}{$\begin{array}{l}X P D \\
\text { Arg156Ar } \\
g \\
\text { codon } \\
156 \\
\text { Ex-6 } \\
\text { C22541A }\end{array}$} & $\mathrm{CC} / \mathrm{CC}$ & $68 / 88$ & $104 / 150$ & $105 / 150$ & $67 / 88$ & $140 / 51$ & $32 / 187$ & $122 / 31$ & $50 / 207$ \\
\hline & $\begin{array}{l}\text { CC/AA+ } \\
\text { AA/AA }\end{array}$ & $54 / 62$ & $94 / 100$ & $95 / 11$ & $53 / 52$ & $113 / 29$ & $35 / 133$ & $98 / 19$ & $50 / 143$ \\
\hline & $\begin{array}{l}\text { OR } \\
(95 \% \mathrm{CI})\end{array}$ & $\begin{array}{l}1.12 \\
(0.69- \\
1.82)\end{array}$ & $\begin{array}{l}1.35 \\
(0.73-1.97)\end{array}$ & $\begin{array}{l}12.33 \\
6.29- \\
24.76) \\
\end{array}$ & $\begin{array}{l}1.33 \\
(0.81- \\
2.20)\end{array}$ & $\begin{array}{l}1.41 \\
(0.84- \\
2.38) \\
\end{array}$ & $\begin{array}{l}1.53 \\
(0.90- \\
2.60)\end{array}$ & $\begin{array}{l}1.31 \\
(0.69- \\
2.46)\end{array}$ & $\begin{array}{l}1.44 \\
(0.92-2.26)\end{array}$ \\
\hline & $\mathrm{P}$ value & 0.62 & 0.11 & $<0.0001$ & 0.25 & 0.18 & 0.11 & 0.40 & 0.10 \\
\hline \multirow{4}{*}{$\begin{array}{l}X P D \\
\text { Ile199Me } \\
t \\
\text { codon199 } \\
\text { Ex-8 } \\
\text { C23047G }\end{array}$} & $\mathrm{CC} / \mathrm{CC}$ & $22 / 81$ & $18 / 173$ & $24 / 169$ & $16 / 85$ & $25 / 53$ & $15 / 201$ & $30 / 31$ & $10 / 222$ \\
\hline & $\begin{array}{l}\mathrm{CC} / \mathrm{CG}+ \\
\mathrm{GG} / \mathrm{GG}\end{array}$ & $100 / 69$ & $180 / 77$ & $176 / 91$ & $104 / 55$ & $228 / 27$ & $52 / 119$ & $190 / 19$ & $90 / 127$ \\
\hline & $\begin{array}{l}\text { OR } \\
(95 \% \mathrm{CI})\end{array}$ & $\begin{array}{l}5.33 \\
(3.04- \\
9.36)\end{array}$ & $\begin{array}{l}22.46 \\
(12.91- \\
39.09)\end{array}$ & $\begin{array}{l}13.61 \\
(8.28- \\
2.30)\end{array}$ & $\begin{array}{l}10.04 \\
(5.37- \\
8.79)\end{array}$ & $\begin{array}{l}17.90 \\
(9.62- \\
3.30)\end{array}$ & $\begin{array}{l}5.85 \\
(3.15- \\
10.85)\end{array}$ & $\begin{array}{l}10.33 \\
(5.18- \\
20.57)\end{array}$ & $\begin{array}{l}15.73 \\
(7.90- \\
31.32)\end{array}$ \\
\hline & $\mathrm{P}$ value & $<0.0001$ & $<0.0001$ & $<0.0001$ & $<0.0001$ & $<0.0001$ & $<0.0001$ & $<0.0001$ & $<0.0001$ \\
\hline \multirow{4}{*}{$\begin{array}{l}X P D \\
\text { Asp312As } \\
n \\
\text { codon312 } \\
\text { Ex-10 } \\
\text { G23591A }\end{array}$} & GG/GG & $63 / 86$ & $103 / 138$ & $126 / 150$ & $74 / 74$ & $129 / 42$ & $37 / 182$ & $104 / 29$ & $62 / 195$ \\
\hline & $\begin{array}{l}\text { GG/GA+ } \\
\text { AA/AA }\end{array}$ & $58 / 64$ & $95 / 112$ & $108 / 110$ & $46 / 66$ & $124 / 38$ & $30 / 138$ & $116 / 21$ & $38 / 155$ \\
\hline & $\begin{array}{l}\text { OR } \\
(95 \% \mathrm{CI})\end{array}$ & $\begin{array}{l}1.23 \\
(0.76- \\
20.0)\end{array}$ & $\begin{array}{l}1.13 \\
(0.78-1.65)\end{array}$ & $\begin{array}{l}1.16 \\
(0.81- \\
1.66)\end{array}$ & $\begin{array}{l}0.69 \\
(0.42- \\
1.14)\end{array}$ & $\begin{array}{l}1.06 \\
0.64-1.75)\end{array}$ & $\begin{array}{l}1.06 \\
(0.62- \\
1.81)\end{array}$ & $\begin{array}{l}1.54 \\
(0.82- \\
2.86)\end{array}$ & $\begin{array}{l}0.77 \\
(0.48-1.21)\end{array}$ \\
\hline & $\mathrm{P}$ value & 0.38 & 0.50 & 0.39 & 0.15 & 0.81 & 0.80 & 0.17 & 0.26 \\
\hline \multirow{4}{*}{$\begin{array}{l}X P D \\
\text { Lys751Gl } \\
n \\
\text { codon751 } \\
\text { Ex-23 } \\
\text { A35931C }\end{array}$} & AA/AA & $62 / 83$ & $106 / 177$ & $110 / 168$ & $58 / 92$ & $130 / 54$ & $38 / 206$ & $111 / 30$ & $57 / 230$ \\
\hline & $\begin{array}{l}\mathrm{AA} / \mathrm{AC}+ \\
\mathrm{CC} / \mathrm{CC}\end{array}$ & $60 / 67$ & $92 / 73$ & $100 / 92$ & $62 / 48$ & $123 / 26$ & $29 / 114$ & $109 / 20$ & $43 / 120$ \\
\hline & $\begin{array}{l}\text { OR } \\
(95 \% \mathrm{CI})\end{array}$ & $\begin{array}{l}1.19 \\
(0.74- \\
1.93)\end{array}$ & $\begin{array}{l}2.10 \\
(1.42-3.10)\end{array}$ & $\begin{array}{l}1.66 \\
(1.14- \\
2.40) \\
\end{array}$ & $\begin{array}{l}2.04 \\
(1.24- \\
3.37) \\
\end{array}$ & $\begin{array}{l}1.96 \\
(1.15- \\
3.33) \\
\end{array}$ & $\begin{array}{l}1.37 \\
(0.80- \\
2.37) \\
\end{array}$ & $\begin{array}{l}1.47 \\
(0.78- \\
2.75)\end{array}$ & $\begin{array}{l}1.44 \\
(0.91-2.27)\end{array}$ \\
\hline & $\mathrm{P}$ value & 0.45 & 0.0002 & 0.007 & 0.004 & 0.01 & 0.23 & 0.22 & 0.11 \\
\hline
\end{tabular}

\section{(D) XPD A35931C codon 751 exon23}

The amplification of XPD codon 751 resulted in the product of $436 \mathrm{bp}$. The PstI enzyme was used to detect the XPDA35931C at codon 751 of exon 23. The PCR amplified products upon treatment with PstI yielded wildtype (35931A) alleles of 290, 146bp fragments, and the polymorphic (C) allele produces 3 fragments of 227, 146 and $63 \mathrm{bp}$ (Figure 1D). The $\mathrm{A} \rightarrow \mathrm{C}$ polymorphism in exon 23 at nucleotide position 35931 gives rise to the amino acid substitution Lys $\rightarrow$ Gln in the codon 751. Table-3 displays the distribution of genotypes and frequency of alleles of the A35931C polymorphisms in patients with head and neck cancer and controls. The distribution of the genotypes in control group was in Hardy-Weinberg 
equilibrium. The frequency of the XPD 35931C allele was not significantly higher in the cases $(16.25 \%)$ than in the controls $(15.00 \%)$ which are at the lower end of the previously reported allele frequencies.

\section{DISCUSSION}

In this hospital based case-control study we investigated the relationship between newly reported genotype polymorphisms of DNA repair genes especially involved in NER pathway and the elevated risk for oral cancer particularly in the users of tobacco and alcohol from the rural areas of south-western Maharashtra. We determined the genotypic frequency of polymorphisms of the NER DNA repair pathway (A) XPD C22541A at codon 156 of the exon 6 (B) XPD C23047G at codon 199 of the exon 8 (C) XPD G23592A at codon 312 in the exon 10 and (D) XPD A35931C at codon 751 in the exon23. To evaluate the association XPD variants and risk of HNC crude and adjusted ORs and their 95\% CIs were calculated using both homozygous genotypes or combined with their respective heterozygous genotypes as the reference groups. Comparable wild type genotype frequencies of XPD codon 156, codon 312, and codon 751 showed wide distribution in the Maharashtrian population in controls as well as HNC cases.

The frequency of allele of the XPD polymorphisms at 22541(C-A), 23591 (G-A), 35931 (A-C) did not show much variation with the oral cancer risk in south-western Maharashtrian population. Also, when we conducted a case-control study to investigate the relationship between the polymorphisms of XPD and the risk of oral cancer in a south-western Maharashtrian population, we find association between the XPD codon 199 at Ile 199 Met polymorphism and smoking and drinking related oral cancer. Previously, Xing D et al reported that the frequencies of Asn allele of XPD 312 and the Gln allele of XPD 751 are 0.06 and 0.07 in hospital based case control study whereas they were reported to be 0.19 and 0.33 respectively by Spitz MR et al. ${ }^{27,28}$ In our study the frequency of Met allele XPD 199 was 0.64 that of XPD 156 allele Arg was 0.13 and that of XPD 312 Asn allele was 0.21 and frequency of XPD 751 allele Gln was 0.16 which were to some extent different from other reports.

The polymorphism in DNA repair genes has been extensively investigated for its associations with cancer risk and the results were conflicting in different types of cancer or different populations. The investigations into the relationship between polymorphisms in DNA repair genes and susceptibility to environmental cancer have not yet produced consistent results. ${ }^{20-30}$ However, there is an inconsistency most likely due to the complexity of the biological process and of molecular epidemiological investigations.

Several molecular epidemiological studies have investigated the association between genetic polymorphisms in XPD and susceptibility to several kinds of cancers including skin cancer, breast cancer, gliomas and bladder cancer among different ethnic including Caucasian, Americans, British and Chinese populations. ${ }^{14,16-19,21}$ Whereas few other studies failed to find positive evidence for XPD polymorphisms in squamous cell carcinoma of the head and neck (SCCHN) or melanoma. ${ }^{20-32}$ Very few studies from Northern and Southern India have reported the genetic polymorphisms in the DNA repair genes with respect to a variety of cancer risks including prostate, breast, oral and esophageal cancers. ${ }^{33-35}$ However, very limited information is available on the association of genetic polymorphisms of DNA repair genes including NER pathway genes and their susceptibility to oral cancer from rural population of Maharashtra where the rate of tobacco and alcohol consumption is very high. Therefore in this study, we aimed to investigate the relationship between the development of oral cancer and genetic polymorphisms in XPD genes with respect to tobacco and alcohol exposure from a pool of unexplored rural Maharashtrian population. Such genotyping analysis of DNA repair genes will enhance our ability to identify those individuals most susceptible to tobacco and alcohol induced carcinogenesis in the rural population of southwestern Maharashtra.

\section{CONCLUSION}

This study is the first time to report the combined effects of XPD gene polymorphisms on the risk of head and neck cancer in Maharashtrian population. Our results showed that the XPD gene at position 23047 of codon 199 of exon 8 polymorphism which could be associated with the risk of oral cancer. This analysis of correlation of DNA repair genes and $\mathrm{HNC}$ may provide a deeper insight into the genetic and environment factors to cancer risk in the rural unexplored population.

\section{ACKNOWLEDGEMENTS}

Authors would like to acknowledge Dr. R K. Ayachit, Director, Health Sciences of Krishna Institute of Medical Sciences for guidance and support to carry out this research. The experimental assistance of Mr. Santosh Jadhav is duly acknowledged.

\section{Funding: Intramural funding by Krishna Institute of Medical Sciences \\ Conflict of interest: None declared \\ Ethical approval: The study was approved by the Institutional Ethics Committee}

\section{REFERENCES}

1. Parkin DM, Bray F, Ferlay J and Pisani P. Global cancer statistics, 2002. CA Cancer J Clin. 2005;55:74-108.

2. Marcu LG, Yeoh E. A review of risk factors and genetic alterations in head and neck carcinogenesis and implications for current and future approaches to 
treatment. J Cancer Res Clin Oncol. 2009;135:130314.

3. Ferlay J, Bray F, Pisani P and Parkin DM. Globocan 2000-cancer incidence, mortality and prevalence worldwide, version 1.0. IARC Cancer Base No. 5. Lyon: International Agency for Research on Cancer. 2001. Available at; http://globocan.iarc.fr/ Default.aspx.

4. Miller CS, Johnstone BM. Human papillomavirus as a risk factor for oral squamous cell carcinoma: a meta-analysis, 1982-1997. Oral Surg. Oral Med, Oral Pathol, Radiol Endol. 2001;91:622-35.

5. Ogden GR. Alcohol and oral cancer. Alcohol. 2005; 35:169-173.

6. Warnakulasuriya S, Sutherland G, Scully C. Tobacco, oral cancer, and treatment of dependence. Oral Oncol. 2005;41:244-60.

7. Frosina G. Overexpression of enzymes that repair endogenous damage to DNA. Eur J Biochem. 2000;267:2135-49.

8. Wood RD, Mitchell M, Sgouros J, Lindahl T. Human DNA repair genes. Science. 2001;291:12849.

9. Scully C, Bagan J. Oral squamous cell carcinoma: overview of current understanding of aetiopathogenesis and clinical implications. Oral Dis. 2009;15:388-99.

10. Evans MD, Dizdaroglu M, Cooke MS. Oxidative DNA damage and disease: induction, repair and significance. Mutat Res. 2004;567:1-61.

11. Lehmann AR. The xeroderma pigmentosum group D (XPD) gene: one gene, two functions, three diseases. Genes Dev. 2001;15:15-23.

12. Manuguerra M, Saletta F, Karagas MR, Berwick M, Veglia F, Vineis P, et al. XRCC3 and XPD/ERCC2 single nucleotide polymorphisms and the risk of cancer: a HuGE review. Am J Epidemiol. 2006;164:297-302.

13. Berwick M, Vineis P. Markers of DNA repair and susceptibility to cancer in humans: an epidemiologic review. J Natl Cancer Inst. 2000;92:874-97.

14. Cagana M, Kilgallen J, Conroy JM, Wiencke JK, Kelsey KT, Miike R. et al. Associations between ERCC2 polymorphisms and gliomas. Cancer Epidemiol. Biomarkers Prev. 2001;10:355-60.

15. Nexo BA, Vogel U, Olsen, A, Ketelsen T, Bukowy $\mathrm{Z}$, Thomsen BL, et al. A specific haplotype of single nucleotide polymorphisms on chromosome 19q13.23 encompassing the gene RAI is indicative of postmenopausal breast cancer before age 55 . Carcinogenesis. 2003;24:899-904.

16. Shao J, Gu M, Xu Z, Hu Q, Qian L. Polymorphisms of the DNA gene XPD and risk of bladder cancer in a Southeastern Chinese population. Cancer Genet. Cytogenet. 2007;177:30-6.

17. Tomescu D, Kavanagh G, Ha T, Campbell H, Melton D. Nucleotide excision repair gene XPD polymorphisms and genetic predisposition to melanoma. Carcinogenesis. 2001;22:403-8.
18. Vogel U, Hedayati M, Dybdahl M, Grossman L, Nexo BA. Polymorphisms of the DNA repair gene XPD: correlation with risk of basal cell carcinoma revisited. Carcinogenesis. 2001;22:899-904.

19. Vogel U, Olsen A, Wallin H, Overvad K, Tjonneland A, Nexo BA. Effect of polymorphisms in XPD, RAI, ASE-1 and ERCC1 on the risk of basal cell carcinoma among Caucasians after age 50. Cancer Detect. Prev. 2005;29:209-14.

20. Sturgis EM, Zheng R, Li L, Castillo EJ, Eicher SA, Chen $\mathrm{M}$, et al. XPD/ERCC2 polymorphisms and risk of head and neck cancer: a case-control analysis.Carcinogenesis. 2000;21:2219-23.

21. Sturgis EM, Castillo EJ, Li L, Eicher SA, Strom SS, Spitz MR, et al. XPD/ERCC2 EXON 8 Polymorphisms: rarity and lack of significance in risk of squamous cell carcinoma of the head and neck. Oral Oncol. 2002;38:475-7.

22. Ramachandran S, Ramadas K, Hariharan R, Kumar RR, Pillai RM. Single nucleotide polymorphisms of DNA repair genes XRCC1 and XPD and its molecular mapping in Indian oral cancer. Oral Oncol. 2006;42:350-62.

23. An J, Liu Z, Hu Z, Li G, Wang LE, Sturgis EM, et al. Potentially functional single nucleotide polymorphisms in the core nucleotide excision repair genes and risk of squamous cell carcinoma of the head and neck. Cancer Epidemiol Biomarkers Prev. 2007;16:1633-8.

24. Bau DT, Tsai MH, Huang CY, Lee CC, Tseng HC, Lo YL, et al. Relationship between polymorphisms of nucleotide excision repair genes and oral cancer risk in Taiwan: evidence for modification of smoking habit. Chin J Physiol. 2007;50:294-300.

25. Majumder M, Sikdar N, Ghosh S, Roy B. Polymorphisms at XPD and XRCC1 DNA repair loci and increased risk of oral leukoplakia and cancer among NAT2 slow acetylators. Int J Cancer. 2007;120:2148-56.

26. Datkhile KD, Vhaval RD, Patil MN, Khamkar TS, Durgavale PP, Gudur A, et al. Role of genetic polymorphisms in DNA repair genes ((XRCC1, XRCC2, XRCC3, XRCC4, XRCC5, XRCC6, $\mathrm{XRCC7)}$ in head and neck cancer susceptibility in rural Indian population: A hospital based casecontrol study from south- western Maharashtra. Int. J. Curr. Res. 2016;8:25482-92.

27. Xing D, Tan W, Wei Q, Lin D. Polymorphisms of the DNA repair gene XPD and the risk of Lung cancer in Chinese population. Lung Cancer. 2002; 38:123-9.

28. Spitz MR, Wu X, Wang Y, Wang LE, Shete S, Amos $\mathrm{CI}$, et al. Modulation of nucleotide excision repair capacity by XPD polymorphisms in lung cancer patients. Cancer Res. 2001;61:1354-7.

29. Benhamou S, Sarasin A. ERCC2/XPD gene polymorphisms and cancer risk. Mutagenesis. 2002; 17: 463-469.

30. Mohrenweiser HW, Wilson DM, Jones IM. Challenges and complexities in estimating both the 
functional impact and the disease risk associated with the extensive genetic variation in human DNA repair genes. Mutat Res. 2003;526:93-125.

31. Kipikasova L, Wolaschka T, Bohus, P, Baumohlová $\mathrm{H}$, Bober J, Blazejov, J, et al. Polymorphisms of the XRCC1 and XPD genes and breast cancer risk: a case-control study. Pathol. Oncol. Res. 2008;14:1315.

32. Winsey SL, Harsh NA, Marsh HP, Bunce M, Marshall SE, Harris AL, et al. A variant within the DNA repair gene XRCC3 is associated with the development of melanoma. Cancer Res. 2000;60: 5612-6.

33. Sobti RC, Singh J, Kaur P, Pachouri S, Siddiqui EA, Bindra HS. XRCC1codon 399 and ERCC2 codon 751 polymorphism, smoking, and drinking and risk of esophageal squamous cell carcinoma in a North
Indian population. Cancer Genet Cytogenet. 2007;175:91-7.

34. Kumar A, Pant MC, Singh HS, Khandelwal S. Associated risk of XRCC1 and XPD cross talk and life style factors in progression of head and neck cancer in north Indian population. Mut. Res. 2012;729:24-34.

35. Mandal R, Gangwar R, Kapoor R, Mittal R. Polymorphisms in base-excision \& nucleotideexcision repair genes \& prostate cancer risk in north Indian population. Indian J Med Res. 2012;135:6471.

Cite this article as: Datkhile KD, Vhaval RD, Patil MN, Khamkar TS, Durgawale PP, Chougule PG, et al. Identification of genetic polymorphisms in DNA repair xenoderma pigmentosum group D gene and its association with head and neck cancer susceptibility in rural Indian population: a hospital based casecontrol study from south-western Maharashtra, India. Int J Res Med Sci 2016;4:1997-2005. 